\section{E-LOGOS}

ELECTRONIC JOURNAL FOR PHILOSOPHY ISSN 1211-0442

$13 / 2010$



University of Economics

Prague

\title{
Ošklivost mezi estetikou a etikou
}

\author{
Jiří Vaněk
}

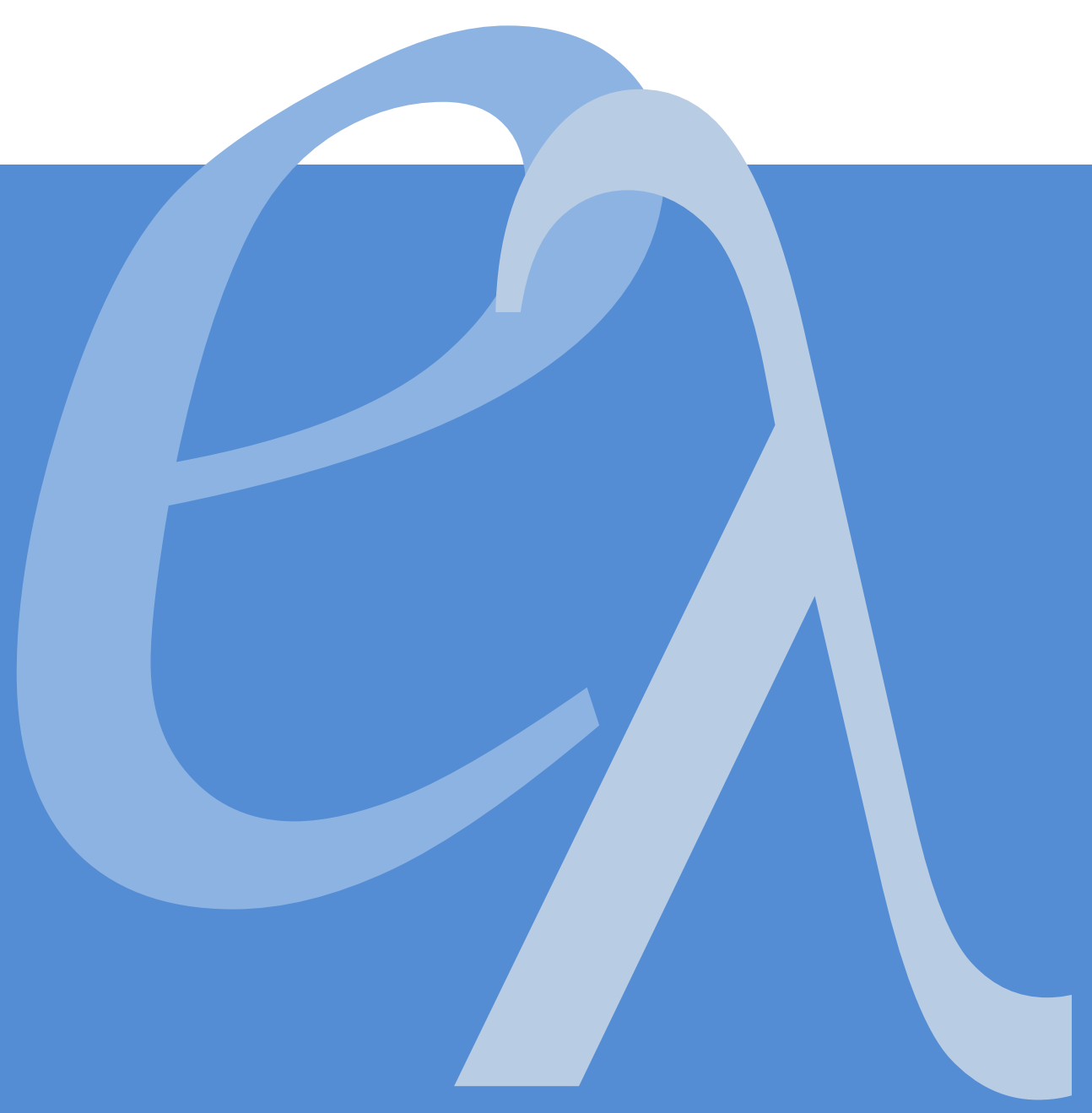




\begin{abstract}
This essay explains the problems with the definition of ugliness as one of the basic aesthetic categories. Here, it is conceived as a deformation of the "right form" of species appearance of objects, whereas the "right form" is not understood as one model, but rather as a dimension. By providing examples from the history of philosophy and visual arts (Neo-Platonism, Michelangelo, modern spiritual art), the necessity to understand ugliness in the wider referential frames is shown. It is also shown in what manner the comparison participates in the final judgment.
\end{abstract}

\title{
Abstract
}

Studie se zabývá tématem ošklivosti, jež je jednou ze základních estetických kategorií. Pojímá ji jako porušení „správné podoby“ druhové formy objektů, přičemž pojem správné podoby neváže k jedinému etalonu. S využitím příkladů z dějin filosofie a výtvarné kultury (neoplatonismu, Michelangelovy tvorby, moderního spirituálního umění) pokazuje k tomu, jak je hodnocení vázáno k širším referenčním rámcům, v nichž se promítá souvislost estetické a etické dimenze fenoménu ošklivosti. Dokládá také, jak se na výsledném hodnocení podílí srovnávání.

\section{Klíčová slova}

ošklivost - zlo - krása - „správná podoba“ - Michelangelo - Nerovný pár - Stanley Spencer - referenční rámec - srovnání.

\section{Keywords}

ugliness - evil - beauty - „right form“ - Michelangelo - Matched Couple - Stanley Spencer - referential frame - comparison. 
Neustále hodnotíme svým pohledem a svými pocity na škále od výhradně pozitivního po krajně negativní. K základním hodnotícím charakteristikám při tom náleží označování něčeho za krásné nebo ošklivé. Univerzálnost těchto charakteristik se projevuje i v tom, že přesahují z estetického posuzování do etické kvalifikace, a to ve vzájemném propojení: týkají se nejen estetických (krása forem), ale i etických hodnot samých (krása dobra), a tím se do okruhu estetického posuzování promítá i etická rovina (krása duchovních jevů, platónská estetika tak sama přerůstá v etiku).

Jestliže byla $\mathrm{v}$ dějinách evropského myšlení věnována výsadní pozornost nejpozitivnější estetické hodnotě a estetika byla mnohdy zúženě definována jako nauka o kráse, zájem současné teorie stále více poutá opačný pól hodnocení. Klade se otázka po jeho objektové stránce (hodnocených vlastnostech) i subjektovém aspektu (zpo̊sobu a průběhu prožívání). A uplatňované zřetele přecházejí z estetiky a etiky dokonce do sociologie (např. hledisko T. W. Adorna).

Uvedené okolnosti vedou k zamyšlení nad možnostmi a proměnami hodnotícího zakoušení takové negativity. Ošklivost se vyjevuje jako kvalita nějakého celku. Ve vztahu celistvého jevu a jeho prvku jde jen o stupeň zošklivění: výrazná nehezkost jedné části způsobuje menší míru odpudivosti, než když se týká celku jako takového, ale stejně zjev tohoto celku poznamenává. Ošklivost se jeví jako porušení a nedostatek. V pozadí hodnocení v tomto smyslu se skrývá zamlčený etalon, vzor, který je v daném případě porušen. Vyvstává tak otázka, vưči čemu jakožto vzoru se hodnocení ošklivosti vymezuje. Nelze automaticky užít analogie s dobrem a zlem, třebaže ošklivost bývala se zlem spojována. Při rozvíjení klasického pojetí, zanechaného Platónem, o jednotě dobra, pravdy a krásy prohlašuje sv. Augustin, že zlo je pouhou absencí dobra. Je tudíž jen jeho mezerou (ale přece i tak jeho přídatkem!), vázaným na esenci, pojmenovanou v základní etické kategorii. Chcemeli tomuto postoji porozumět také na úrovni vnitrosvětské každodennosti, lze jej snad chápat takto: nepřispívám-li aktivně k dobru, už tím způsobuji zlo, dávám mu př́iležitost.

S ošklivostí je tomu zřejmě jinak: není pouhou absencí krásy. Je sice obecně porušením (tedy případně i nedovršením) nějakého etalonu, ale tím etalonem není krása sama. Nelze říci, že vše, co není krásné, je ošklivé. Mezi oběma krajními póly je škála větší a menší výraznosti, „šedá zóna“ různé intenzity. Kolem pomyslného středu mezi póly krásy a ošklivosti je území mdlých charakteristik, jež vnímáme s lhostejností („ani krásné, ani ošklivé“). Porušením krásy může být pouhá nevýraznost, "bezbarvost", ničím nevynikající "plochost“ jakožto plytkost vlastností, ale zjev sám zůstává v mezích "normality“. Ošklivost je teprve přesahem z „normality“ k zápornému pólu hodnocení. Onou „normalitou“ je zřejmě to, co je považováno za "správnou podobu“ daného jevu. Nevylučuje se tím ovšem možnost prohlásit za jedinou tzv. správnou podobu samotný ideální zjev krásy: tak by byli 
př́padně mohli ve starém Řecku vnímat jako ošklivého každého, kdo nevypadal jako Polykleitův DORYFOROS (socha zpodobující tělesný kánon kalokagathie, tj. představy krásného a dobrého člověka) Avšak byl by to jen krajní případ té základní měrné intence, jíž je uvažovaná správná podoba obecně. Správná podoba ještě nemusí být krásná, ale až její jistý stupeň dokonalosti. V tomto smyslu nutno upřsesnit tvrzení G. E. Lessinga, že „ošklivost je nedokonalost". ${ }^{1}$

O ošklivosti jako výmyku ze správné podoby v mezích normality vypovídá Bible v 3. knize Mojžíšově: „Hospodin dále mluvil k Mojžíšovi: ,Mluv k Áronovi: Když se v pokoleních tvého potomstva vyskytne muž, který by měl nějakou vadu, nepřiblíží se, aby přinášel chléb svého Boha. Nepřibližzi se žádný muž s vadou: nikdo slepý nebo kulhavý nebo se znetvořenou tváři nebo s některým údem př́liš dlouhým, nebo kdo by měl zlomenou nohu nebo zlomenou ruku, nebo hrbatý nebo zakrnělý nebo se skvrnou na oku nebo postižený svrabem nebo s lišejem nebo s rozdrcenými varlaty. Nikdo z potomstva kněze Árona, kdo by měl nějakou vadu, se nepřiblíží, aby přinášel ohnivé oběti Hospodinovy. Má vadu, nepřibližź se, aby přinášel chléb svého Boha. Chléb svého Boha z velesvatých i svatých darů smí jíst. Ale nesmí přistupovat k oponě a nepřiblíží se $\mathrm{k}$ oltáři, nebot' má vadu, aby neznesvětil prostory mé svatyně. Já jsem Hospodin, já je posvěcuji.“"2 I když jde pouze o zákaz kněžské funkce tělesně postiženým a ošklivcům je jinak dovoleno přežívat (chléb svého Boha smějí jíst), znamená to diskriminaci, odsun těch, kteři jsou porušeni ve svém zjevu, $\mathrm{z}$ reprezentace lidstva. Člověk je obrazem božím ${ }^{3}$ a pošramocený obraz zastupovat lidstvo nemůže.

Další posun $\mathrm{v}$ tomto pojetí představuje názor, že tělesná ošklivost jako výraz nedostatečnosti lidství se pojí s dalšími nedostatky, totiž charakterovými, a prozrazuje ohavnost morální. G. Hegel ve své Estetice připomíná, jak toho bylo využíváno ve výtvarném umění: „Tím se vyznačují zejména hornoněmečtí mistřii; ve výjevech umučení Páně zvýrazňují hrubost žoldnéřù, zlomyslné vysmívání, barbarskou nenávist ke Kristu v jeho utrpení a umírání; činí to s velkou silou charakterizace oněch ošklivých a nestvưrných stránek, které odpovídají zkaženosti srdce jako její vnější formy." ${ }^{4}$ Vedle Němců ovšem s mimořádnou výrazností vyjádřil tento názor v prvé řadě Hieronymus Bosch, nejvíce snad na té své verzi častěji u něj opakovaného tématu NESENÍ KǨÍŽE (1515-16), jež je nyní uložena v Gentu. V monstrózní galerii tváří, obklopujících Krista, promlouvá nízkost, hanebnost a překypělá zloba.

\footnotetext{
${ }^{1}$ Lessing, G. E.: Hamburská dramaturgie. Láokoón. Stati. Praha 1980, s. 363.

23. Mojžíšova kniha, 21, 16-23. Bible, ekumenický překlad, Ekumenická rada církví v ČSR, 1984, 104.

${ }^{3}$ Viz 1. kniha Mojžíšova, 1,26. Tamtéž, s. 17.

${ }^{4}$ Hegel, G. W. F.: Estetika, II, Praha 1966, s. 167.
} 
U Bosche však obludnost přerostla v zobecnění, týkající se stavu celého lidského světa. Ošklivost v podobě groteskních srostlin, hrůzných zámotků a děsivých útvarů jako vyjádření morálního úpadku dozrála tu ke svému vrcholu v hemživém světě zrůd. Je to zpodobení ideje „převráceného světa“ a zvrácenost je vystižena právě prorůstáním jednotlivých úrovní bytí (anorganické, organické, lidské i uměle člověkem vytvořené) $v$ jednotlivých zjevech. Svět původních hodnot je naopak úhrnem v sobě sourodých identit.

Zdroj zla, spojeného s nestvůrností zjevu, s poruchou a nedoceleností „správné podoby“, je pak spatřován vabsenci vnitřní celistvosti, nerozeklané identity, nefragmentarizované integrity. Ohlas tohoto pojetí zaznívá až do nové doby a lze jej zaznamenat např́íklad u Lautréamonta. Jeho Zpěvy Maldororovy jsou proloženy třemi zdánlivě tematicky si vzdálenými ódami: na oceán, hermafrodita a matematiku. Pokaždé však vyjadřují tutéž základní myšlenku: všechna tři témata jsou symbolem docelenosti, vnitřní jednoty, jejíž nedostatek způsobuje zlo, ztělesněné v titulní postavě a z ní odvozených dějích. ${ }^{5}$ A i zde jde se zlem ruku v ruce ošklivost, sadisticky vyjádřená $\mathrm{v}$ hyperbole. Niterná nedocelenost se pojí s porušeným vzhledem.

Jednota zjevu a duchovních hodnot je však chápána jen v jedné kulturní linii. Projevovala se kupř. i v pojetí Krista jako "Krásného Boha", "Beau Dieu“ ve francouzské gotice 13. století, jak o tom svědčí Spasitelova socha na vstupním pilíri katedrály v Amiensu. V jiné kulturní tendenci je naopak mezi hodnotami smyslově vnímaného vzezření a hodnotami spirituálními disproporce, ba až protiklad. Ten také zná křestáanská tradice. Tělo trpícího Ukřižovaného je mnohdy extrémně ošklivé, aby se tím znázornila prodělaná muka. Porušené je na straně dobra, na straně zla jsou porušitelé, jejichž eventuální zjevná ohavnost je pak teprve znetvořením, spojeným s etickým záporem.

Zakoušené porušení nebo nedostatečnost ovšem závisí také na poměřovaném etalonu. Tím může být vzor harmonické sladěnosti prvků podle zákonů klasického pojetí krásy (na způsob někdejších tělesných kánonů) nebo určité hranice takříkajíc přípustného zjevu $\mathrm{v}$ rámci druhové podoby. K tomuto druhému pojetí pobízejí již v minulosti takové koncepční výkony jako Dürerova typologie lidské postavy a Burkovo chápání „běžné úplné formy“. Albrecht Dürer se vzdal původní představy jediného ideálního kánonu krásy a pokusil se (v souladu s nastupujícím duchem moderní vědy) stanovit př́ísně geometrickými metodami rozličné „charakteristické typy“ lidských postav; napočítal jich šestadvacet (navíc ještě s dodatkem př́ikladu dětského těla). Tak má být exaktně rozhodnutelné, co překračuje variantní přípustné

\footnotetext{
5 Srv. Lautréamont, Comte de: Zpěvy Maldororovy, Praha 1967, s. 50. Též viz Kundera, L. ve studii Hyperbolik, Tamtéž, s. 28.
} 
míry a stává se abnormálním, groteskním, ošklivým. ${ }^{6}$ Edmund Burke později naopak zcela odmítl proporční estetiku, zároveň však požadoval varietní model krásy. Ošklivost pak pojímá tradičně jako protiklad krásy. ${ }^{7}$ Protože však ve skutečnosti není vše ošklivé, čemu chybí krása, lze Burkeovu konceptu rozumět spíše jako odlišení takříkajíc polyfonní normy od toho, co je již jejím porušením. Když takto přetlumočíme jako myšlenkovou iniciativu, lze říci, že to, co nazývá „běžnou úplnou formou“ je možné rozpětí rozmanitých podob v rámci určitého druhu jevů. Účelně utvářená druhová forma je jako modifikovaný aristotelský telos pojata nikoliv jako optimum (optimální tvar), nýbrž jako rozmezí. Tak netřeba lidské jedince i jiné živé bytosti s navzájem odlišnými proporcemi hodnotit esteticky negativně, pokud nepřesáhnou základní vzhled (formu) svého rodu a druhu, tedy pokud u nich nedojde k zásadním deformacím. Ve formulaci „ne míra, ale forma vytváří všechnu krásu týkající se tvaru“8 se mírou míní nějaká konkrétně stanovená závazná proporce, kdežto pod slovem forma tu má Burke na zřeteli obecné vzezření druhu, do něhož náleží každý jeho jednotlivý exemplář. Může-li nás toto pojetí inspirovat k představě oné "správné podoby“, jež se neomezuje na jediný etalon, lze pak domýšlet dále: krásou je až rozvinutí té či oné varianty „správné podoby“ v určitých kvalitách, at' již se týkají skladebnosti nebo různé výraznosti, souladnosti, jež může obsahovat vnitřní kontrasty a napětí atp. Sotva možno to nejpozitivnější estetické působení, označované za krásu, vyčerpat nějakou normativní katalogizací. Krásou se sice mnohdy stávají běžné formy až ve vypjaté kvalitě, svým rozvinutím, předestřením, reprezentací (způsobem, jak se nám dávají), ale také jsou jí nadány i ty nejprostší věci, pokud se soustředěně otevřeme jejich tiché př́itomnosti, jejich obsahu, jejich smyslu. Tohle objevoval Vincent van Gogh u Japonců: „Studujeme-li japonské umění, pak zjištujeme, že jeho tvưrcem je člověk nesporně moudrý, přemýšlivý a inteligentní. A čím ten se zabývá? Zkoumáním vzdálenosti Země od Měsíce? Nikoli. Studiem Bismarckovy politiky? K čemu vlastně? Ne, pozoruje pouhé stéblo trávy. Ale po stéblu trávy kreslí všechny rostliny, pak roční období, konečně zvírata a nakonec lidskou figuru. Tráví tak svůj život, ale život je přiliš krátký, aby mohl udělat všechno. - Poslyš, není to skoro pravé náboženství, čemu nás učí tito Japonci, kteří žijí v prrírodě tak prostě, jako by sami byli květinami?" ${ }^{9}$ Krása tkvějící v prosté jednoduchosti bývá zacloněna zvykem opakované každodenní zkušenosti s věcmi.

A ohlašuje se i druhá strana téže mince, totiž různé zpo̊soby ošklivosti a jejich prožívání. Třebaže porušení či nedostatek takové „správné podoby“ (v širokém

\footnotetext{
6 Blíže viz Panofsky, E.: Význam ve výtvarném umění, Odeon, Praha, 1981, s. 77n..

7 Burke, E: O vkuse, vznešenom a krásnom, Tatran, Bratislava, 1981,s.107.

8 Tamtéž, s.91.

9 Gogh van V.: Dopisy, Státní nakladatelství krásné literatury, hudby a umění, Praha 1955, s. 553 (z Arles mezi 20.2.1888 - 8.5.1889).
} 
smyslu slova je takovým nedostatkem i př́ipadný nadbytek, hypertrofie některých částí celku) může působit ošklivě v realitě i v jejím uměleckém zpodobení, nutno odlišit věcnou ošklivost $v$ reálném světě (at' již by byla recipována jako kvalita o sobě nebo vzešlá z deformace druhově přípustných proporcí) od jejího uměleckého zpodobení, jež samo má také dvojí stránku. V uměleckém díle může být ošklivost vyjádřena věcně, ale způsob vyjádření lze vnímat jako esteticky pozitivní zážitek (modelem je výrok: To je ale ošklivá ženská, ale jak krásně namalovaná!). Obojí se pak v souhře zážitkových plánů podílí na celkovém zakoušení díla.

V dalším si povšimneme estetického účinku věcného zpodobení ošklivosti, vycházejíce $\mathrm{z}$ předpokladu, že $\mathrm{k}$ zdrojům ošklivosti náleží spolu $\mathrm{s}$ deformací nedocelenost $\mathrm{v}$ poměru $\mathrm{k}$ "správné", třebas variantní podobě daného celku, jehož př́ikladem může být ve shodě s dosavadními vývody lidské tělo. Kdy dochází $\mathrm{k}$ tomu, že neúplnost až fragmentárnost je někdy vnímána jako ošklivost a jindy nikoli?

Vyvstává otázka odlišné recepce různých typů fragmentů. Ve sféře umění se klade tím více, že moderní tvorba, zejména počínaje sochařským dílem Augusta Rodina, předkládá mnohdy fragment jako dokončené, hotové dílo. ${ }^{10}$ Čím to, že tělesný fragment, který označíme jako pahýl, nebo jeho obraz působí ošklivě, avšak fragmentární útvar nazývaný torzem nikoliv? Nutno přitom ještě odlišit torzo vzniklé poškozením pưvodního celku (jako jsou některé antické památky jako např. tzv. BELVEDERSKÉ TORZO nebo NÍKÉ SAMOTHRÁCKÁ) od torza zanechaného tvůrcem záměrně $\mathrm{v}$ neukončené podobě jako hotový výtvor. Torza způsobená pošramocením recipujeme ve skladbě dochovaných složek a zároveň na pozadí někdejšího faktického a nyní jen pomyslného celku. Do estetické recepce vstupuje historické povědomí a konotace kulturních kontextů.

Pozoruhodnější ovšem je druhý okruh fragmentárních útvarů, tj. torza záměrně vzniklá. K takovým se přidružují i díla, jež zůstala jakoby v neukončeném stavu, když tvůrce předpokládané dotvarování odkládal tak dlouho, až k němu nedošlo. A pokud to nebyl záměr vědomý, lze předpokládat, že se tu prosadilo výslovně neformulované, ale niterně zažité přesvědčení, že ponechaný stav je zatím jedině přijatelné vyjádření. To je př́ipad Michelangelových OTROKŮ, určených původně do skupiny soch u náhrobku Julia II. U Michelangela to na první pohled může udivit, nebot' tento umělec je znám svými pevnými tvary, přesným obrysem, jasnou linkou kresby. Erwin Panofsky v tom spatřuje výtvarný projev neoplatonismu, názoru, že tělo je vězením duše, tj. hlediska protikladného filosofickému názoru Leonarda da Vinci. Zatímco Michelangelovy figury jsou v prostoru vymezeny, plastický objem Leonardových postav ( $v$ důsledku užití techniky sfumatu) je s jejich prostředím

10 Zde chceme rozvinout východiska, jež jsme zformulovali v knize Zpưsoby estetického prožívání, Galerie Zdeněk Sklenár̆, Praha 2009. 
spojen. U Leonarda „„... duše není vězněna tělem, ale tělo - lépe řečeno, ,kvintesence' jeho materiálních elementů - je spoutáno duší." ${ }^{11}$ Michelangelovu preferenci modelování kresbou je tedy možno chápat jako výsledek jeho sdílení neoplatonismu, jenž panoval v duchovní atmosféře Florencie od časů Cosima Medicejského, který zde založil neoplatonskou akademii, získavší brzy evropskou proslulost. Nicméně se nabízí dodatek, že smyslová krása nachází svůj výraz právě v tomto vymezení forem.

Zdánlivě paradoxně, ale vlastně v logice věci samé, jsou druhou stránkou téhož názoru Michelangelovi OTROCI. A to především ti čtyři jakoby nehotoví, uchovávaní ve Florentské Akademii, nikoliv ona dvojice dokončených rabů, obdivovaná v Louvru. Ovšem i tihle z Louvru již obsahují také neoplatonskou ideu, jak o tom vypovídá Panofsky: symbolizují nikoliv individuální otroctví, ale „otroctví jako třídu“, totiž vše ",subhumánní" v člověku. ${ }^{12}$ Pokračujeme-li v úvaze naznačené tímto směrem, nabízí se nedokončenou čtveřici otroků z Florencie recipovat jako výsledný produkt přesvědčení, že vyjádřit ve hmotě duchovní významy spojené s lidstvím je nemožné. A přitom lze tato díla zároveň zakoušet jako reprezentaci pozemského stavu utváření, proklubávání tvaru v neukončeném procesu duchovního projevu v tělesném a nedostupnosti úplného docelení. Jako by se zde vytrácela původní rabskost $\mathrm{v}$ tom vzepětí hmoty ke své formě, jež je nutně neukončeným gestem. K této formulaci nás vedou i další Panofského poukazy: dokonce i tam, kde jsou lidská těla podána v pevném obrysu, jako je tomu v Michelangelově BITVĚ U CASCINY, jejich pohyby ztuhly a zůstaly nedokončeny, jako by svalově napětí nedospělo k efektivnímu výsledku. ${ }^{13}$

Torzo lidského těla v podobě Michelangelových OTROKŮ z florentské Akademie nevnímáme jako ošklivé, protože je recipujeme $\mathrm{v}$ rámci širších významových kontextů. na pozadí sémantického horizontu, přesahujícího pouhou fyzickou nedostatečnost. Proto mohou být velmi působivá i moderní torza zhotovená záměrně, jako je tomu např́ílad u mnohých soch Rodinových. Katedrála, bronzová plastika Augusta Rodina o výšce $63,5 \mathrm{~cm}$, sestává jen ze sepnutých rukou, zpodobených od zápěstí a vertikálně směřujících $v$ modlitebném gestu $\mathrm{k}$ nadpozemskému transcendentnu. Oproti tomu useknuté lidské údy na obraze Theodora Géricaulta ANATOMICKÉ FRAGMENTY jsou předestřeny jako syrová realita těla-masa $\mathrm{v}$ jeho zranitelnosti, utrpení a konečnosti (tomu sice odpovídá též brutální prezentace objektů, ale rozhodující pro recepci zůstává významový rámec, z něhož je právě i tato prezentace odvozena). Recepce díla takto závisí na

11 Panofsky, E.: Studies in Iconology (Humanistic Themes in the Art of Renaissance), Harper \&Row, New York - London 1972, 182.

12 Viz tamtéž, s. 195.

${ }^{13}$ Viz tamtéž, s. 177. 
významovém pozadí, v jehož rámci se odvijí a nedocelenost, neúplnost či porušení celistvé formy nezpůsobuje sama o sobě ošklivost. I v těchto zážitkových polohách rozhoduje až obsahový kontext.

Ošklivost se může vyjevit nebo zesílit $\mathrm{v}$ prožitkovém rámci při srovnání. Trochu ošklivé působí v přímé konfrontaci s poněkud lepším ještě ošklivěji. Ve výtvarném umění se významový rámec srovnání uplatňoval zvlášt' úspěšně v tématu Nerovný pár. Existuje pro to velký počet př́kladů zejména v období renesance, manýrismu a baroka, ale i v moderní době pozdější se umělci tímto způsobem vypořádávají s tématem ošklivosti: lze to sledovat od Dürerova žáka Hanse Baldunga Griena (1484/85 - 1545; NEROVNÝ PÁR, 1507), posedlého vůbec ve svém díle osudovostí stárnutí, a zejména od Lucase Cranacha staršího s jeho sérií vyhotovenou mezi léty 1520 a 1532, v níž si stařec namlouvá mladou ženu zjevně za peníze a výjimkou je i ukázka stejného počínání staré ženy s mladým mužem. Podobné umělecké svědectví zanechali nizozemští manýristé Quentin Massys (1465/66 - 1530) a (v několika známých variantách) Hendrick Goltzius (1558 - 1617), stejně jako rudolfinský manýrista Hans von Aachen (1552 - 1615) ve svých KUPLÍŘSKÝCH SCÉNÁCH (asi 1610). Vlámský barokní mistr hospodských scén David Teniers ml. (1610 - 1690) také navazuje na tuto tradici: MUŽ A STARŠÍ ŽENA (1634), STARÝ ROLNÍK OBJÍMÁ VE STODOLE POMOCNICI KUCHAǨKY (kol 1650). Z českých barokních umělců rovněž Václav Hollar zpodobil mladíka a stařenu ve chvíli úplaty (údajně podle předlohy Leonarda da Vinci) a u Petra Brandla nacházíme NEROVNÝ PÁR U NOTÁŘE (asi před r. 1700). Goya pak (CAPRICHOS č. 14, 1799) omlouvá námluvy hrbatého ošklivce soucitnou poznámkou v doprovodném textu: "Jak už to tak chodí, nepatří ženich právě $\mathrm{k}$ těm nejžádoucnějším, ale je bohatý a za svobodu nešt'astného děvčete se vykoupí podpora pro hladovějící rodinu. Takový je už běh světa."14 I $\mathrm{v}$ devatenáctém století lze nalézt znovu oživované téma Nerovného páru: u Josefa Navrátila (1861) v městském výjevu nebo v podání německého realisty Wilhelm Leibla (1844 - 1900) v selské scéně. Tak se srovnání výrazně podilí na vymezování a posuzováni ošklivosti. Kuriózním způsobem to dotvrdil vobraze z roku 1925 NEROVNÝ PÁR německý expresionista Otto Dix (1891 - 1969), když u obou protagonistů výjevu vydatně uplatnil vysokou míru ošklivosti i s jistým odstupněním, na němž se podílí rozdílný věk postav, a zároveň tím dosáhl hyperbolizace ohavného zjevu. V tématu Nerovný pár se v uvedených souvislostech navíc prostupuje ohavnost estetická s ošklivostí morální. Nicméně uvedené

\footnotetext{
14 Goya Francisco y Lucientes, Caprichos, Státní nakladatelství krásné literatury, hudby a umění, Praha
} 1956, s. 30. 
konfrontace zároveň názorně dotvrzují, jak ošklivost lze chápat také jako „text času“ 15

Tento zásadní významový horizont však vnáší do estetického zakoušení ošklivosti podstatný prvek smiřování se s realitou. Obhajobu ošklivého proti diktátu vzorců krásy přinesl už preromantismus osmnáctého století a romantismus ve století devatenáctém. Předznamenání těchto tendencí lze ovšem zaznamenat již v manýristické estetice. Tak Georgio Comanini v básni k Arcimboldově obrazu RUDOLF II. JAKO VERTUMNUS napsal: „... a nespatříš-li při zkoumání ošklivost, jež mne činí krásným, nejspíš nevíš, že ošklivost předčí každou krásu. "16 Ošklivost má podle toho silnější vypovídací hodnotu než krása.

Klíčovými momenty $\mathrm{v}$ tomto duchovním pohybu byly proklamace Williama Gilpina a Victora Huga. Gilpin se v Eseji o pitoreskní kráse, vydaném r. 1792, dožaduje proti požadavku uhlazené krásy, vyhlášenému Edmundem Burkem, práva uznat za pravou estetickou hodnotu drsnou skvělost rozbitých forem, již nazývá pitoreskností ve smyslu malebnosti (nikoliv v druhém a dnes obvykleji vnímaném významu jakési výstřední rozmanitosti). A Hugo r 1827 v Předmluvě ke svému dramatu Cromwell vyhlásil nárok umění zpodobovat život v celé jeho šíři tak, jak do něj patří i vše ošklivé. ${ }^{17}$

Prodloužením této vnitřně proměnlivé myšlenkové linie je ve dvacátém století stanovisko Theodora $W$. Adorna. Ošklivé v moderním umění je podle něj sociálním protestem svého druhu a tento protest je vyjadřován již v rovině uměleckého výrazu, vnitřními principy umění samého. Tak revolučnost Picassovy Guerniky vychází z „nehumánní konstrukce“ formy, z rozkladu forem, ne z nějaké doprovodné proklamace antifašismu. „Ve sklonu nového umění k tomu, co je hnusné a fyzicky odporné, proti němuž apologeti existujícího stavu neumějí namítnout nic silnějšího než, že to, co existuje, je již dost ošklivé, a tudíž zavazuje umění k marnivé kráse, proráží kriticky materialistický motiv tím, že umění svými autonomními tvary obviňuje moc, i takovou, která sublimovala v duchovní princip, a svědčí pro to, co tato moc potlačuje a popírá.“18

Sublimované, tj. kvalitativně povýšené vyjádření moci v kráse měl na zřeteli také neznámý autor nápisu v pařížském metru z r. 1985: „Formy vašeho útlaku budou estetikou našeho hněvu“. Podepsán byl „Punk“ a za ním uvedeno číslo. „Punk“ v původním významu znamenal "zkažený", „zkrachovalý". Tomu odpovídá

15 Metaforický termín, který užívá v teoretické analýze nezávisle na našem odkazu k uměleckému ztvárnění tématu Nerovný pár M. Gagnebinová, Dějiny ošklivého, in: Umění, krása, šeredno (Texty $z$ estetiky 20. století), Karolinum, Praha 2003, s. 321-340.

16 Kriegeskorte W, Giuseppe Arcimboldo, Taschen-Slovart, Bratislava 2003, s. 46.

17 Hugo, V.: Předmluva ke Cromwellovi, Kant, Praha 2006, s. 39-40.

18 Adorno, T. W., Estetická teorie, Praha 1997, s. 70. 
záměrné popírání uhlazené formy jako výraz opozice vůči řádu: rehabilituje se rozcuchanost, odřenost, otrhanost, roztřepenost, rozježenost. ${ }^{19}$

Ošklivé vyvstává v protikladu (ev. v odporu) vůči cizorodému pozadí. Můžeme předpokládat, že maliř graffiti zřejmě konfrontuje špičaté a klikaté tvarosloví, jež si vzal za své jako vizuální způsob protestu, s uhlazeností bílé zdi, jež jej provokuje. Jeho výtvarný projev je často hodnocen jako ošklivý nikoliv sám o sobě (ač leckoho mohou odpuzovat $v$ graffiti preferované tvary jako agresivní), ale především právě na pozadí celku (zdi, budovy), kam jsou násilně vepsány.

Prezentace a reprezentace ošklivosti se může dít ve znamení vzdoru a protestu, ale ten se odráží od významového pozadí nároků krásy a nároků na krásu. Existuje však ještě sémantická pozice přitakání realitě v její nevyběravé podobě, a sice jako souznění překračující estetický horizont - opět do hájemství etiky. Tuto pozici zřejmě sdílel ve svém životě i ve svém uměleckém vyjádření svérázný spirituálně založený anglický malíř Sir Stanley Spencer (1891 - 1959). Zvlášt' je to patrné z jeho cyklu obrazů nazvaného BLAŽENOSTI LÁSKY z r. 1938. Objevují se na nich postavy, které jako by spolu až na pomezí karikatury závodily, kdo z nich je ošklivější, a přitom se radostně jeden ve druhém shlížejí a vstřícně sdílejí své společenství. Sám autor o nich napsal: „Tyto páry svými zjevy neodpovídají tomu, co se běžně považuje za krásné, podle mne však vyjadřují krásu toho zázraku, který spočívá v tom, jak si uvědomují svůj vzájemný vztah. “20 Umělcově volbě objektů na jeho obrazech údajně odpovídal i výběr partnerek a přátel v životě. U Spencera je dána životní příležitost ošklivosti, ošklivost ve své vzájemnosti, v zrcadlení nachází zalíbení, svět spasený před reglementujícími, omezujícími kritérii krásy.

Chtěli jsme naznačit různé možnosti estetického posuzování směrem ke krajnímu negativnímu pólu ošklivosti, v jejichž varietě figurovaly jako určité milníky také hodnotové postoje jako 1. představa o ošklivosti jakožto nedokonalosti, neúplnosti ve vazbě jak k porušení pýthagorejské proporcionality, tak ke kráse duše v antice, 2. pozice, podle níž nedokonalost, nedokončenost, neúplnost hmoty je komplementaritou krásy duchovní (jako v neoplatonismu) a 3. výzva ke konfrontaci s ošklivostí reality (Adorno), jež může přerůst v prožitek, kdy duchovní krása je spatřována v realitě ošklivosti samé (jak dosvědčuje dílo S. Spencera). Vždy záleží a) na celkovém referenčním rámci, $v$ němž jsou příslušné hodnoty posuzovány, i b) na komparačních vektorech, tj, jaké hodnoty jsou srovnávány (jak dokládá příklad typu Nerovný pár).

Ve variantách fenoménu ošklivosti a jejího prožívání se vyjevuje víceznačná souvislost estetické a etické dimenze bytí a jeho umělecké reprezentace. Tyto

${ }^{19}$ Viz Nahoum-Grappeová, V.: Kánony ošklivosti, in Umění, krása, šeredno, cit. vyd, s. 277.

20 Bell, K: Stanley Spencer, Phaidon Press Inc., London 2002 (1. vyd. 1992), s. 153. 
kontexty lze zároveň chápat jako pobídku k hledání a nalézání křehké rovnováhy mezi estetickým a etickým zakoušením života. 


\section{Bibliografie}

Adorno, T. W., Estetická teorie, Praha 1997.

Bell, K: Stanley Spencer, Phaidon Press Inc., London 2002.

Burke, E: O vkuse, vznešenom a krásnom, Tatran, Bratislava, 1981.

Gagnebinová, M. Dějiny ošklivého, in: Uměni, krása, šeredno (Texty z estetiky 20. století), Karolinum, Praha 2003.

Gogh van V.: Dopisy, Státní nakladatelství krásné literatury, hudby a umění, Praha 1955.

Goya Francisco y Lucientes, Caprichos, Státní nakladatelství krásné literatury, hudby a umění, Praha 1956.

Hegel, G. W. F.: Estetika, II, Praha 1966.

Hugo, V.: Předmluva ke Cromwellovi, Kant, Praha 2006.

Kriegeskorte W, Giuseppe Arcimboldo, Taschen-Slovart, Bratislava 2003.

Lessing, G. E.: Hamburská dramaturgie. Láokoón. Stati. Praha 1980.

Lautréamont, Comte de: Zpěvy Maldororovy, Praha 1967.

Nahoum-Grappeová, V.: Kánony ošklivosti, in Uměni, krása, šeredno (Texty z estetiky 20. století), Karolinum, Praha 2003.

Panofsky, E.: Význam ve výtvarném umění, Odeon, Praha, 1981.

Panofsky, E.: Studies in Iconology (Humanistic Themes in the Art of Renaissance), Harper \&Row, New York - London 1972.

Vaněk, J. Způsoby estetického proživáni, Galerie Zdeněk Sklenář, Praha 2009. 


\section{E-LOGOS}

\section{ELECTRONIC JOURNAL FOR PHILOSOPHY}

Ročník/Year: 2010 (vychází průběžně/ published continuously)

Místo vydání/Place of edition: Praha

ISSN 1211-0442

Vydává/Publisher:

Vysoká škola ekonomická v Praze / University of Economics, Prague

nám. W. Churchilla 4

Czech Republic

13067 Praha 3

IČ: 61384399

Web: http://e-logos.vse.cz

Redakce a technické informace/Editorial staff and technical information:

Miroslav Vacura

vacuram@vse.cz

Redakční rada/Board of editors:

Ladislav Benyovszky (FHS UK Praha, Czech Republic)

Ivan Blecha (FF UP Olomouc, Czech Republic)

Martin Hemelík (VŠP Jihlava, Czech Republic)

Angelo Marocco (Pontifical Athenaeum Regina Apostolorum, Rome, Italy)

Jozef Kelemen (FPF SU Opava, Czech Republic)

Daniel Kroupa (ZU Plzeň, Czech Republic)

Vladimír Kvasnička (FITT STU Bratislava, Slovak Republic)

Jaroslav Novotný (FHS UK Praha, Czech Republic)

Jakub Novotný (VŠP Jihlava, Czech Republic)

Ján Pavlík (editor-in-chief) (VŠE Praha, Czech Republic)

Karel Pstružina (VŠE Praha, Czech Republic)

Miroslav Vacura (executive editor) (VŠEE Praha, Czech Republic) 